\title{
Chapter 16 Technologies, Incentives and Cost Recovery: Is There an Israeli Role Model?
}

\author{
Christine Bismuth, Bernd Hansjürgens, and Ira Yaari
}

\begin{abstract}
This chapter focuses on water policy reforms and the introduction of a new water pricing policy in Israel. These reforms have to be seen in combination with measures to extend the available water sources that have been introduced in Israel in recent years. The effects of the Israeli demand and supply management policy on the use and availability of the water resources is investigated, and the potential transferability of the Israeli experiences to other countries in the region is examined. We also discuss the contribution of the water policy reforms as part of possible options and alternatives to the planned RSDS Conveyance Project.
\end{abstract}

Keywords Water policy $\bullet$ Water management institutions $\bullet$ Water pricing $\bullet$ Water use $\bullet$ Desalination $\bullet$ Wastewater treatment $\bullet$ Water consumption $\bullet$ Agriculture $\bullet$ Levies • Israel national water system

\subsection{Introduction}

Israel's water policies in recent years have presented its end users with two diametrically opposite modus operandi: from one point of view, Israel can be seen as a pioneer in agricultural water-saving technologies and water desalination projects (OECD 2011), and from the other view, Israel is wasting water, using the majority

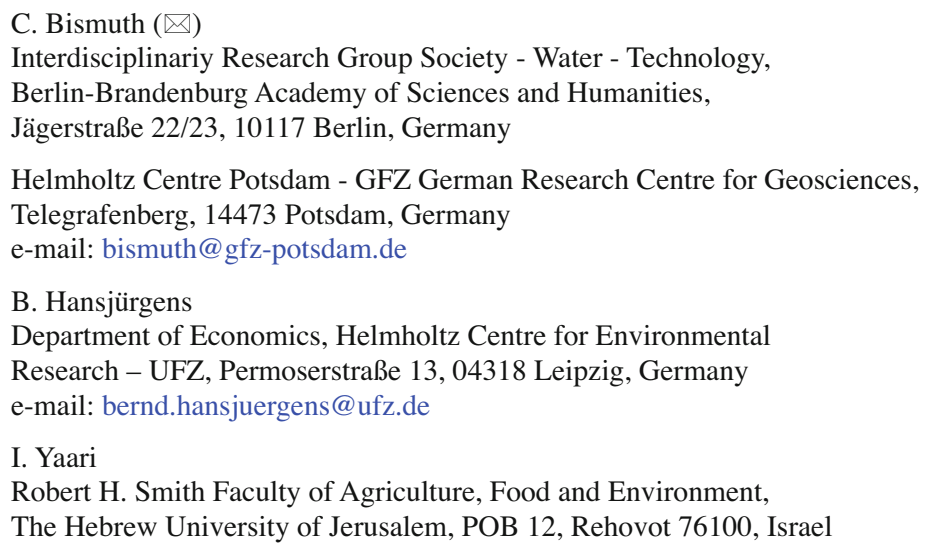


of the Jordan River's water resources and overexploiting the aquifers which are shared with the Palestinians (Amnesty International 2009).

In the 1990s and in the first decade of the third millennium, Israel was confronted with the impacts of a series of drought years. Several reports revealed that with respect to water, to continue with a "business as usual" policy was not possible. Israel reacted with the introduction of technical innovations in the water sector and a reform of water management institutions and pricing policies.

Some of these measures could be looked upon as being the adaptation of existing major water engineering projects (MWEPs), such as the Israel Water Carrier, or even being a second-generation MWEP.

Does the reform mean a shift away from the traditional technology-centred approach (MWEP logic)? And how have the reforms influenced the discussion around the Red Sea-Dead Sea Conveyance Project and its possible options?

\subsection{The Evolution of Israel's Water and Agrarian Policy}

From the first Zionist settlements, water in conjunction with land had been the driving force for the development of Israel's society and economy. Working the land was strongly linked to the Zionist ideology (Lipchin 2007). Modern agricultural techniques were introduced in Palestine not only by the Jewish settlers but also by Christian religious settlements from America and German Pietism movements (Kark 1983). A major influence stemmed not only from the introduction of modern agricultural techniques but also from the commercial marketing methods introduced by Baron de Rothschild who transferred all his properties and interests from his Palestinian settlements (moshavim) to the Jewish Colonization Association. Right from the beginning of Jewish expansion in the late nineteenth century, there was a difference between the subsistence system of the local Arab communities and the European model, based on cash crop plantations and shaping the Jewish settlements (Aaronsohn 1995). Jewish settlers did not come from traditional agrarian societies, but had a more urban background. From the commencement, the settlers invested not only in modern technologies and fertilisers, but they also improved the water supply devices within the settlements (ibid.). The strong ties and close communication between agricultural research and the farmer communities, most of whom had an excellent education, though not necessarily in agriculture, and the strong ties of the research communities with the Kibbutzim were determining factors for the high innovation rate within the Israeli agriculture. When compared to other agricultural societies, their pace of practical implementation in agricultural innovation has been considerably slower (Katz and Ben-David 1975).

Israel's Water Law of 1959 declared water as a public good, and its management was given into the responsibility of state institutions (Lipchin 2007). Any abstraction of water and any use of water require a permit. The requirement to monitor and measure the water was already included in the 1955 Water Measurement Law (Feitelson 2013). Since then, the water management system of Israel has been highly centralised. Its main purpose was subordinated to agricultural uses (Feitelson et al. 2007). 
The water law also foresaw the institution of a "Water Commissioner" whose task was to monitor and allocate water rights. The Water Commission itself was supposed to be composed of two thirds of the general public, but the commission was dominated by representatives from the agricultural sector receiving 13 out of the 39 representative positions allocated (Plaut 2000). Until 2000, the Minister of Agriculture was the supreme statutory authority for the formulation of Israel's water policy. Also the Knesset Finance Committee, which was supposed to supervise the water policies, was dominated by agricultural lobbying groups (ibid.). As a result of these policies, water prices in the agricultural sector did not reflect the scarcity of the resource.

Instead, the agricultural sector was highly subsidised, and crops with a high water consumption rate such as cotton, citrus and flowers became profitable. Not only are these crops not adapted to the arid climatic conditions, but also they require high quantitative and quality water (Lipchin 2007).

In his 1990 report, Israel's state comptroller heavily criticised the existing water policies. In addition, the 2000 report was very critical of government pollution prevention policies (Plaut 2000). In 1997, the Arlosoroff Commission recommended to reduce agricultural water uses and change the institutional structures dominated by the agricultural sector (Feitelson 2001, cited in Lipchin 2007). However, it took nearly another decade and a couple of years of severe drought brought on by the political lock-in until the propositions favouring agriculture were taken down. This policy shift was underpinned by breaking up Mekorot's monopoly as Israel's only water supplier (Feitelson 2013).

Since 2007, Israel has gradually implemented several measures to overcome the water crisis. The main measures were:

1. Reform of the water management institutions

2. Enlargement of the water supply by different technical solutions (construction of sea water desalination plants on the Mediterranean coast, upgrading existing and construction of new wastewater recycling plants, use of the effluents for irrigation)

3. Introduction of economic incentives (water prices) to manage demand

4. A campaign to raise public awareness.

\subsection{Reform of the Water Management Institutions}

In 2007, the Israel Water Authority was created to replace the former Water Commission. The "Governmental Authority for Water and Sewage" (Israel Water Authority) gradually gathered all regulatory bodies concerning water issues under its authority. The main objective of the 2007 reform was to

$[\ldots]$ enable the Authority implementing an integrative management of the whole 'water chain' and to transfer authorities from the political level of several ministers to one professional board. (Israel Water Authority 2012a, p. 1)

This has come into reality and today the Israel Water Authority is in charge of the management and regulation of the national water sector according to the water law. 
The responsibilities of the Israel Water Authority include the preservation and regulation of the water resources. This includes the production (from seawater), the supply and use of water, the design and implementation of water supply schemes and the allocation and price setting for all water sectors (private households, agricultural and industrial) (OECD 2011). The Israel Water Authority intervenes in the sphere of withdrawal from the natural sources. Withdrawal without a permit is not possible. The Israel Water Authority issues permits at the beginning of each year according to hydrological considerations. Therefore, these permits differ from year to year (Kislev 2011). The users are required to present their requirements for the next year to the Israel Water Authority.

The Israel Water Authority Council has the primary responsibility for taking the water-related decisions. The council consists of eight elected members: the head of the Israel Water Authority as chairperson of the Israel Water Authority Council; one representative each from the Ministry of Agriculture and Rural Development, the Ministry of Environmental Protection, the Ministry of Interior and Management of Local Authorities, the Ministry of Finance, and the Ministry of Infrastructure; and two delegates of the public. The public representatives are appointed by the Minister of National Infrastructure. Kislev (2011, p. 136) criticised that the public representatives "cannot be taken as a realisation of public involvement".

With the creation of the Israel Water Authority, operations for managing waste and wastewater services were gradually transferred to water and sewerage corporations according to the Water and Sewage Association Law of 2001. This transfer of responsibility from the municipalities to the corporations was supposed to boost the construction of wastewater treatment plants. Before the reform, the financial resources required for the construction of wastewater treatment plants were not made sufficiently available to the municipalities (Hophmayer-Tokich 2010). As part of the reform, all revenues from water tariffs have now to be reinvested in water infrastructure (OECD 2011). The Israel Water Authority lists 55 corporations, which provide services for 6.2 million citizens in 147 local authorities (out of 187 local authorities bound by law). The law does not apply to the West Bank, regional councils and water associations. The largest corporation serves 415,000 residents in Tel Aviv; the smallest serves only 14,000 residents. The Israeli public criticises the number of the corporations as too many, and plans for merging corporations exist.

The government cut financial assistance and imposed restrictions on the use of water revenues for those municipalities that did not form corporations, while it provided financial assistance to those municipalities which formed corporations (Kan and Kislev 2011).

The partial privatisation of Mekorot and the shift to call for bids, as one of the results of the governmental market liberalisation efforts, opened up a new financing mechanism in Israel (public-private partnership, PPP) and started the era of large desalination projects.

One of the major achievements of the political reforms in the water sector was the introduction of the full cost recovery principle. In 2002 the agricultural ministry accepted that subsidies for the agricultural sector were shifted from water to land subsidies, which allowed raising prices for agricultural water uses (Menahem and 
Gilad 2013). In 2006 the government signed an agreement with farmers' representatives according to which prices for agriculture would be set according to the costs of Mekorot for supplying water to agriculture (Kislev 2013). By 2015 the full cost recovery principle should be applied to agriculture.

As a result of the institutional reforms, Israel increased investment in water infrastructures, but compared to the energy sector, these increases have been far less significant (Israel Central Bureau of Statistics 2014).

\subsection{Desalination}

The 1997 master plan already foresaw the implementation of large-scale seawater desalination plants (Tenne et al 2013), but it took until 2000 - following a severe drought - for the Minister of Finance to reverse his position of not financing largescale desalination plants and to issue a tender (Feitelson 2013). According to Feitelson, the issue of such a tender has been the turning point in decreasing the costs of desalination plants. But according to Becker (2010), desalination was still not the lowest cost alternative to close the water gap. Therefore cost reduction was one of the major concerns in the realisation of Israel's national planning programme for desalination. Besides the large-scale seawater desalination capacities, which today achieve an overall capacity of $577 \times 10^{6} \mathrm{~m}^{3} /$ year, desalination capacities for brackish water exist for an additional $60 \times 10^{6} \mathrm{~m}^{3} /$ year. This brackish water comes from groundwater wells (Tenne 2010).

In Israel desalination plants have to follow all public tender and bid procedures. With the exception of Ashkelon, which is operated by Mekorot, all seawater desalination plants are financed, constructed and operated by private companies (ibid.). But in fact, only two companies (Mekorot and IDE) exist on the Israeli market increasing the risk of possible monopolistic market structures. The desalination facilities in Israel are financed via a build-operate-transfer (BOT) contract. The concessionaires design, build and operate the plants over a period of 26.5 years after which the plant is transferred to state ownership (Spiritos and Lipchin 2013, p. 2014). During the time of operation, the companies receive the water revenues as private gains.

To reduce costs for the private investors of desalination plants, they are allowed to build power plants together with the desalination facilities, where the energy is not only used for the plants' own energy provision but sold into the national energy grid at their own profit (Tenne 2010).

Along the Mediterranean coast, Israel has constructed five seawater desalination plants (see Fig. 16.1). The Sorek plant is the newest and largest, with a desalination capacity of $150 \times 10^{6} \mathrm{~m}^{3} /$ year. The long-term master plan foresees a seawater desalination capacity of up to $750 \times 10^{6} \mathrm{~m}^{3} /$ year until 2020 .

It was necessary to reshape the national water grid to integrate the new desalination plants in the water distribution system. The National Water Carrier transports water from north to south, but with the construction of the desalination plants, water 


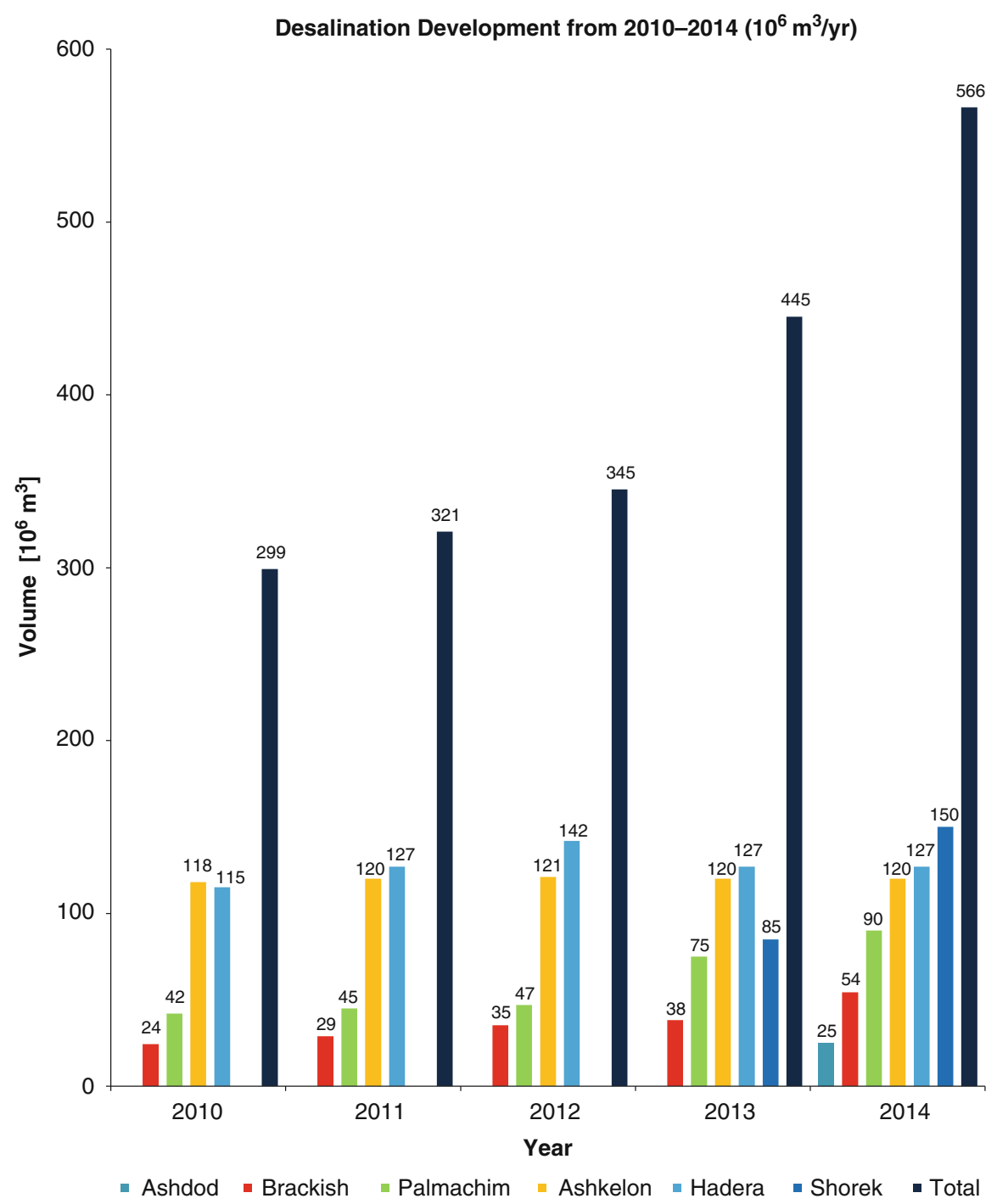

Fig. 16.1 Desalination development from 2010 to $2014\left(10^{6} \mathrm{~m}^{3} / \mathrm{year}\right)$ (Data source: Israel Water Authority (2014a))

had to be brought from the Mediterranean shoreline to the municipal centres. New lines from west to east were connected to the national water grid. With the extension of the drinking water network, the irrigation water network (recycled wastewater) had to be extended too (see Fig. 16.2).

The costs for desalinated water are highly dependent on energy costs, which make up more than $50 \%$ of total costs. Consequently, energy saving is promoted in Israel for the desalination plants. As Israel discovered large natural gas reserves in 


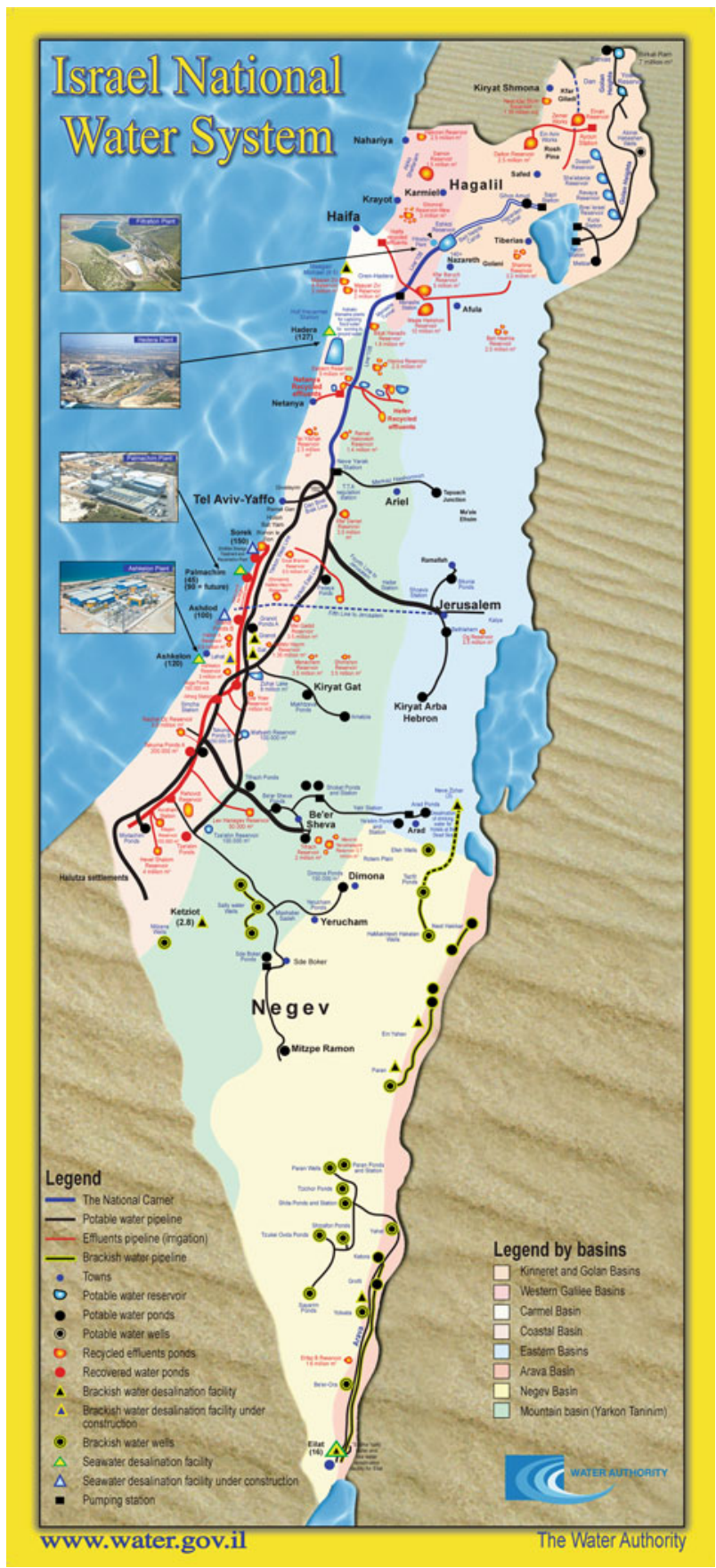

Fig. 16.2 Israel national water system (Source: Israel Water Authority) 
2010, natural gas power generation is favoured for the desalination plants, while the national power system is still based on coal.

The prices for desalinated water are composed of a fixed price component for capital costs and a variable price component for variable costs, mainly for electricity prices (Lokiec 2011). The variable price is paid according to the quantity of water actually delivered, while the fixed price is paid according to the facilities' capacity. The prices of desalinated water from Israel's seawater desalination facilities are among the lowest worldwide. The national average is at USD 0.65; Sorek desalination plant is at USD 0.52 (Tenne 2010).

Cohen (2011) carried out a survey on the environmental impact of seawater desalination in Israel. He concluded that the Ashkelon, Palmachim and Hadera plants have no significant impact on the ecosystems of the receiving environments. One of the limiting factors for the construction of new seawater desalination plants in Israel is the limited space on Israel's shorelines. Therefore, planned construction of future seawater desalination plants will be offshore (Tenne 2014, personal communication).

The water from the desalination plants has improved the water supply quality both for private households and agricultural uses. Hardness and salinity were reduced. This has had positive effects on lifetime of heaters and other household devices, and the productivity of agriculture was increased due to lowered salinity levels in the water supplied to agriculture (Tenne et al. 2013).

The water from the desalination plants is introduced into the National Water Carrier (see Fig. 16.3). The desalination plants must operate continuously in order to get the fixed cost component financed through water sales (Dreizin et al. 2008). Changes in water demand are therefore adjusted by inputs from the various "natural" water supply sources (e.g. groundwater). As a result of the water privatisation policy, the management of the supply is more oriented towards the goal of reducing costs. This means that domestic users may be provided with water from other sources than desalinated water and that agriculture may also use water from desalination instead of using treated wastewater. This led to conflicts between the policy of the Israel Water Authority with its objective of saving water and taking water from wastewater reuse and the actual supply management of the desalination plants and Mekorot (Tenne et al. 2013) that is oriented towards using the full amount of desalinated water available.

\subsection{Extension of Wastewater Treatment Plants}

In $201196 \%$ of the Israeli population was connected to an urban wastewater treatment system (Fig. 16.4). Most of the wastewater treatment plants are characterised by either secondary or tertiary treatment level. The water from tertiary treatment is unrestricted for irrigation uses. With the enlargement of the treatment capacities, new stringent quality parameters were introduced. 


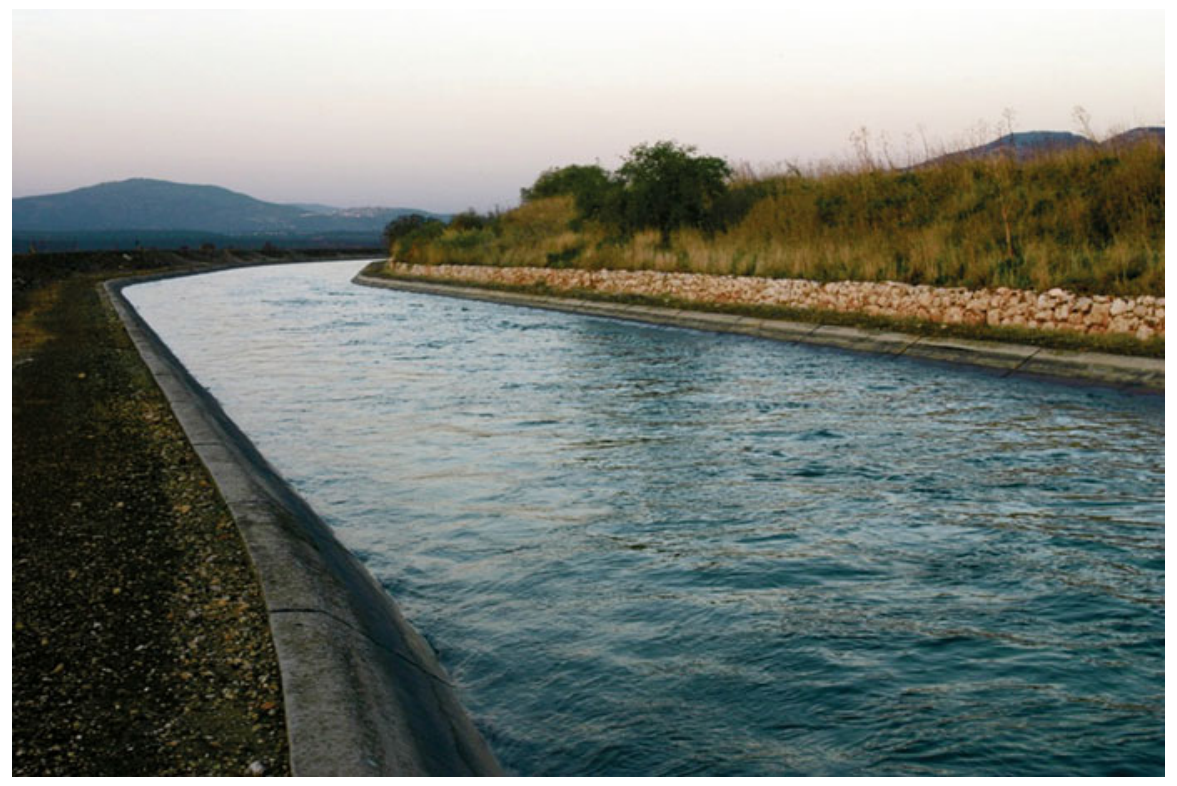

Fig. 16.3 National Water Carrier of Israel (Photo: Mekorot)

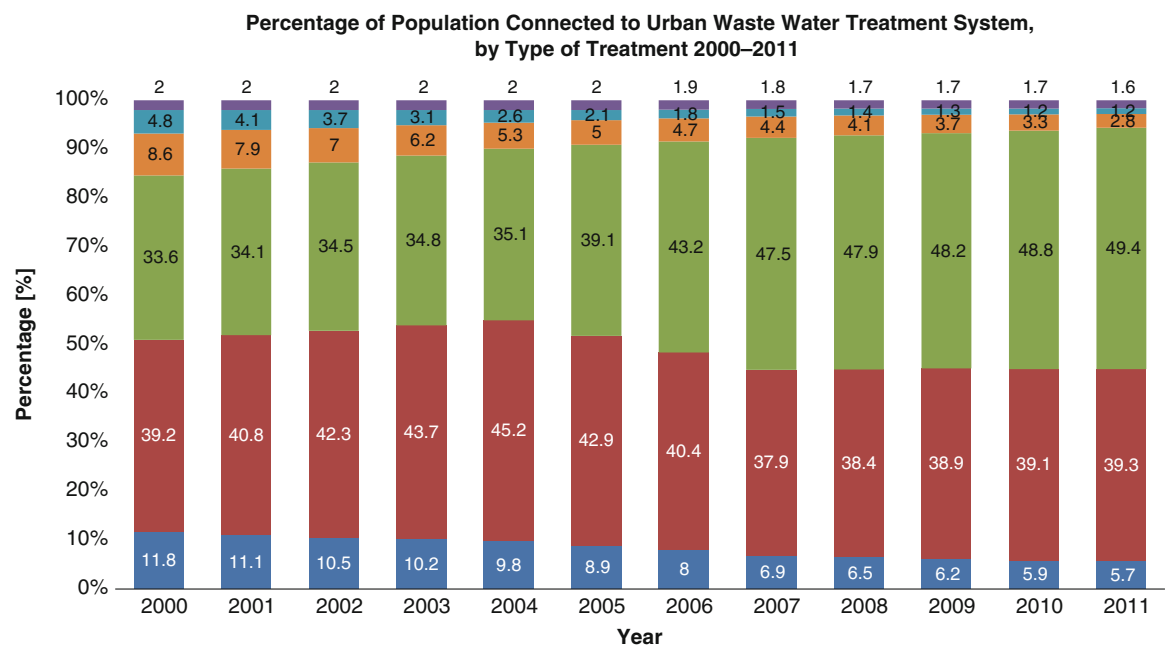

॥ Primary treatment $\approx$ Secondary treatment $\approx$ Tertiary treatment $\approx$ No treatment $\approx$ Independent treatment $\approx$ Other treatment

Fig. 16.4 Population connected to an urban wastewater treatment system, by type of treatment and level of treatment (Source: Israel Central Bureau of Statistics (2013a, p. 38)) 
From 2002 to 2013, Israel invested nearly 2.8 billion New Israel shekel (NIS) (approx. USD 734 million) in wastewater infrastructure and wastewater reclamation plants. Another 1.5 billion NIS (USD 393 million) will be invested in the near future. Not only were 100 water treatment plants built or upgraded, but a separate wastewater pipeline network, including a $90 \mathrm{~km}$ pipeline to the Negev, had to be built for the country (Israel Water Authority 2014a). In 2012, agriculture used $429 \times 10^{6} \mathrm{~m}^{3}$ of recycled wastewater (ibid.). For 2014, it was required that $50 \%$ of the agricultural water uses should come from recycled wastewater; according to the National Water Plan, this share is supposed to rise to more than $90 \%$ by 2050 (Israel Water Authority 2012b). The rest will flow back to nature.

Stringent effluent quality standards came into effect in 2010. The regulations set maximum levels for dissolved and suspended elements and compounds and for 36 other parameters regarding effluents (European Environment Agency 2014). They came into effect to minimise the risk of soil and groundwater contamination by the use of wastewater for irrigation.

Apparently there is a conflict of interest between agriculture and environmental protection about the use of treated wastewater effluents. In the summer of 2014, the Israel Water Authority did not permit the use of treated wastewater for the rehabilitation of the Kishon River in the Haifa area. The Ministry of Environmental Protection had to suspend further river rehabilitation plans because of the decision of the Israel Water Authority (Israel Ministry of Environmental Protection 2014). This example might also illustrate a lack of coherence between the river rehabilitation plans and the national water management plans issued by the Israel Water Authority.

Environmentalists have criticised the partial dumping of the remaining sludge into the Mediterranean. The sludge from the Shafdan sewage plant contributes at least $75 \%$ and up to $98 \%$ of the total load to the Israeli marine environment. It is planned that this source will be terminated by the end of 2015 (European Environment Agency 2014).

\subsection{Economic Instruments and Incentives}

As a consequence of the restructuring of the water management institutions, the Israel Water Authority was able to considerably increase the prices for domestic water uses. The Israel Water Authority signed an agreement with the agricultural representatives that in 2015 the full cost recovery for agricultural water uses should be introduced. So far low water prices for the agricultural sector were crosssubsidised by higher water prices for domestic uses.

The water prices in Israel are set as a part of the general water law. The Israel Water Authority is responsible for establishing the water prices, and it does so according to the rules set by the Ministry of Finance, the Prime Minister's Office and the Ministry of National Infrastructures, Energy and Water Resources (Water.org.il 2014).

The current model for establishing the water prices is based on three main principles (Israel Water Authority 2014a): 
Table 16.1 Water consumption distribution

\begin{tabular}{l|l|l|l|l|l|l}
\hline & $\begin{array}{l}\text { Low block } \\
\text { rate }(\%)\end{array}$ & $\begin{array}{l}\text { High block } \\
\text { rate }(\%)\end{array}$ & Price a (\%) & Price b (\%) & Price c (\%) & $\begin{array}{l}\text { Gardening } \\
\text { price }(\%)\end{array}$ \\
\hline 2007 & - & - & 46.4 & 16.0 & 19.1 & 18.4 \\
\hline 2008 & - & - & 48.8 & 17.2 & 18.6 & 15.4 \\
\hline 2009 & - & - & 56.8 & 18.5 & 19.1 & 5.6 \\
\hline 2010 & 57.1 & 42.9 & - & - & - & - \\
\hline 2011 & 65.2 & 34.8 & - & - & - & - \\
\hline 2012 & 71.7 & 27.7 & - & - & - & - \\
\hline
\end{tabular}

Data source: Israel Water Authority (2014b)

Note: Between 2009 and 2010, there was a change in the water tariffs

1. Equal treatment: The price of water from all water corporations should be equal for all end consumers (except for industrial consumers - they have different prices due to different sewage components).

2. Block tariffs: Water prices for domestic uses are staggered in block tariffs. The first block goes up to $3.5 \mathrm{~m}^{3}$ per capita and month. The approved quantity for a single member household is fixed to $7 \mathrm{~m}^{3}$. According to Kislev (2011), only in few cases for small households with high consumption is a higher block rate likely to be applied. Table 16.1 shows the share of consumers paying different tariffs. The figures for 2010 to 2012 clearly indicate that water-saving measures for domestic consumption had been effective - the amount of households charged with a high block rate decreased considerably from 42.9 to $27.7 \%$. One reason is that private household can receive state support for the installation of watersaving devices. The reduction of freshwater consumption for domestic purposes was accompanied by the increase of treated wastewater uses for gardening, as quotas of water for watering private gardens had been cancelled (Kan and Kislev 2011). Also municipalities increasingly use recycled wastewater for the irrigation of public gardens and parks (ibid.).

3. Full cost recovery: The prices of water are set according to the costs of providing water for the municipalities, including coverage of all expenses (operating and maintenance costs, interest for capital costs for financing water-related infrastructures, calculatory costs).

The tariffs for domestic consumption are cost recovery rates. ${ }^{1}$ These rates have two components (Fig. 16.6):

\footnotetext{
${ }^{1}$ It should be mentioned here that the cost recovery principle in Israel is based on a "company perspective". This means that the costs mirror all the necessary resources to safeguard the existence of a company - the company assets (operation and maintenance costs, capital costs for foreign capital, calculatory costs for company's own capital). This company-oriented concept of cost calculation goes beyond the "refinancing" perspective of cost recovery, which refers to the refinancing of company's expenditures (this does not include, e.g. calculatory costs). However, it does not include so-called social costs that mainly refer to the costs of environmental degradation; see Hansjürgens (1997). In Israel, this concept has led to increasing investments in water-related infrastructures, as the companies can receive money from the capital market.
} 


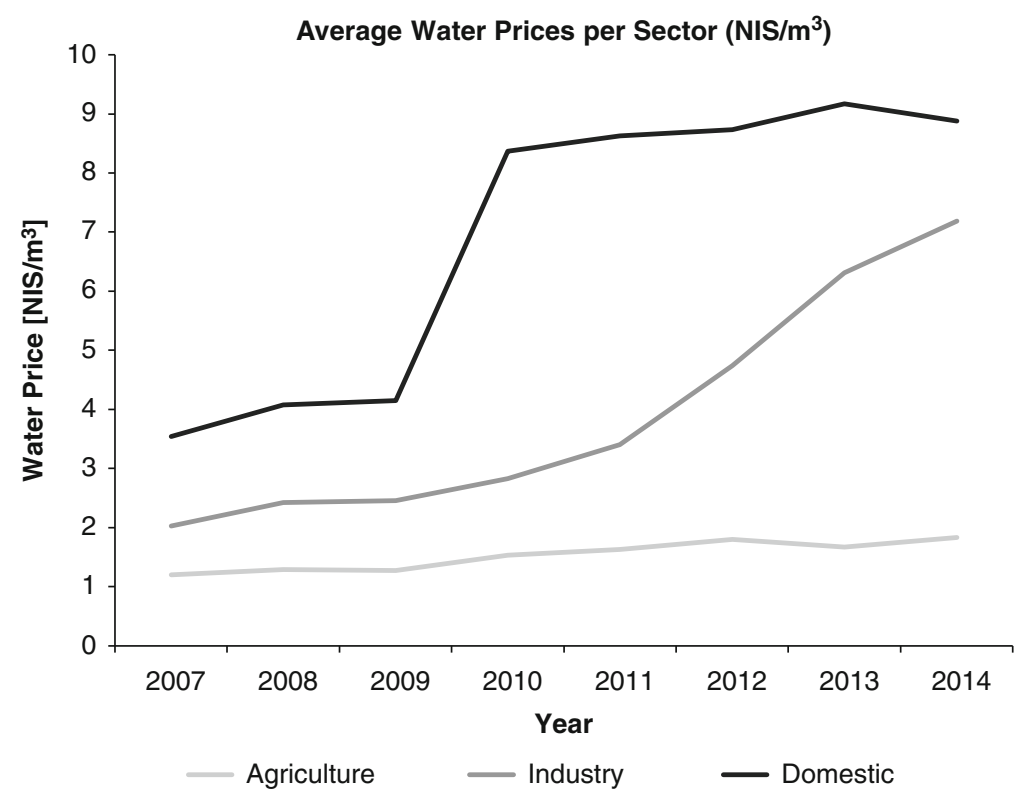

Fig. 16.5 Average water prices for agricultural, industrial and domestic water uses from 2007 to $2014\left(\mathrm{NIS} / \mathrm{m}^{3}\right.$ ). One New Israeli shekel (NIS) is equivalent to USD 0.26 (value as of November 2014) (Data source: (Israel Water Authority 2014b, c), Israel Central Bureau of Statistics (2012))

(a) "Costs for purchasing water from Mekorot at the municipality gate and costs for seawater desalination, wastewater treatment and subsidies".

(b) Costs for water distribution, sewage collection and wastewater treatment within the municipalities.

For a closer look on the tariff structure, we refer to Kislev (2011).

Water supply for agriculture is organised by an administrative allotment of quotas. Trading of the quotas among the agricultural companies is permitted under restricted conditions.

Figure 16.5 shows the evolution of the average water prices (NIS) for the agricultural, industrial and domestic sector from 2007 to 2014. Water prices for the domestic sector increased from 2007 to 2014 by $151 \%$, while in 2014, for the first time, the prices had been lowered by approx. $3 \%$. Prices for the agricultural sector increased between 2007 and 2014 by approx. $52 \%$ and for the industrial sector approx. $254 \%$. Compared with other sectors, such as the energy sector, price rises had been less significant. The prices for energy augmented from 2011 to 2013 up to $31 \%$, compared with $6.3 \%$ for price increases in the water sectors for the same period (Israel Water Authority 2014a). The share of household expenditures on water services and related services compared with total consumption expenditures is about $1.1 \%$, compared to an average $2.4 \%$ in the EU (Israel Water Authority 2014a). 


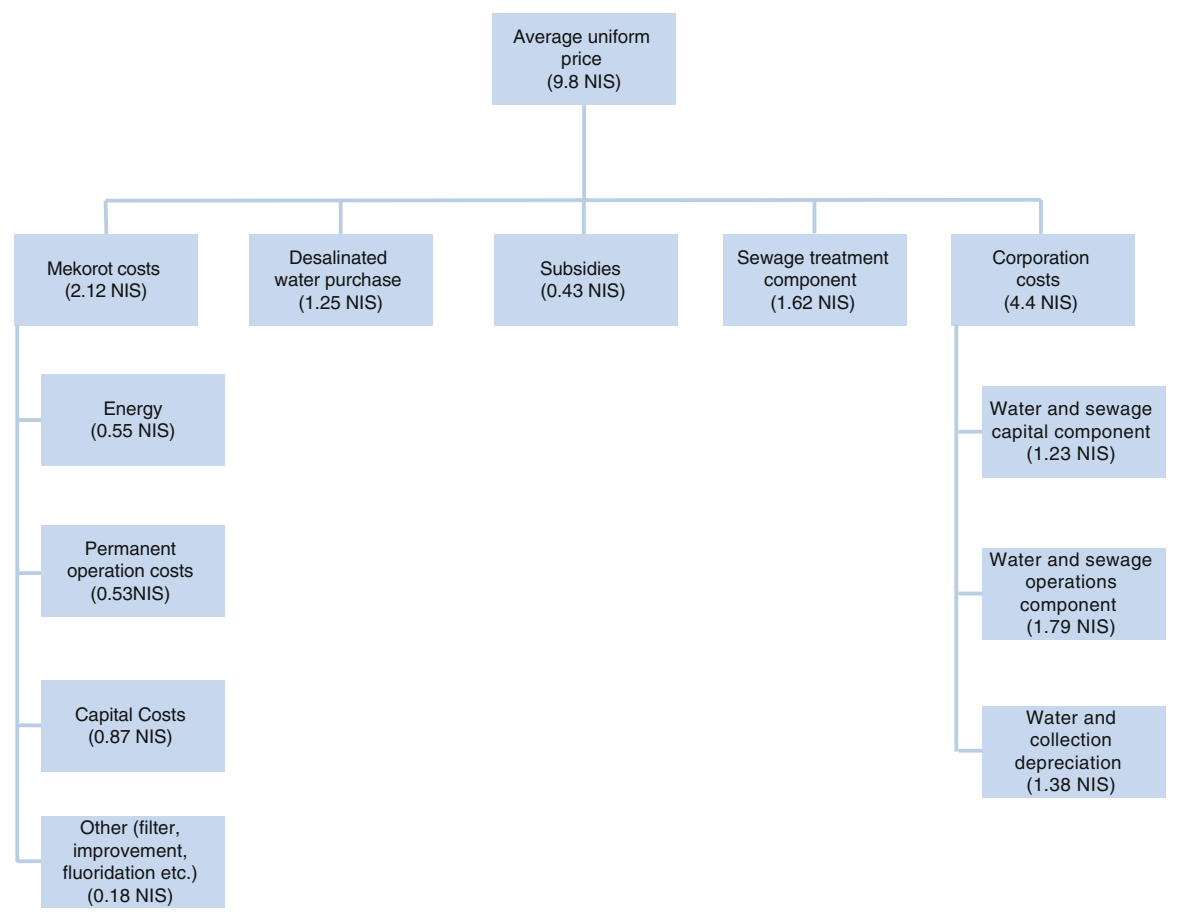

Fig. 16.6 Main components in the average uniform price of water for $2014\left(\mathrm{NIS} / \mathrm{m}^{3}\right)$ (Data source: (Israel Water Authority 2014b, c))

For comparison, the consumer price index for the period between 2007 and 2014 is $20.9 \%(2006=100)$ according to the data provided by the Israel Central Bureau of Statistics (CBS).

Certain population groups such as disabled people, victims of hostilities and people who are qualified to receive social welfare transfers receive governmental support. This support allows these groups of people to double their amount of water used; however, they still have to pay the price for the low block tariff - instead of $3.5 \mathrm{~m}^{3}$ per capita and month, these individuals can use $7 \mathrm{~m}^{3}$ per capita a month for the low block tariff rate. The Knesset Finance Committee decides which population groups are eligible to receive this benefit, while the eligibility is decided by the Social Security (Bituach Leumi). The support itself comes from the local water corporation retroactively and is shown on the water invoice.

Figure 16.6 shows the components of the average uniform price. The corporation costs component ( $45 \%$ ) makes up the highest share, followed by the costs for Mekorot, which represents the costs of provisioning drinking water. The sewage treatment component is about $16 \%$, and the component for desalinated water is about $13 \% .4 \%$ goes to subsidies. From 2007 to 2014, the costs for water provision were nearly constant.

The decisive point here is that water prices ease the financing of MWEPs and, thus, cause path dependencies for expanding water-related infrastructures. Once 


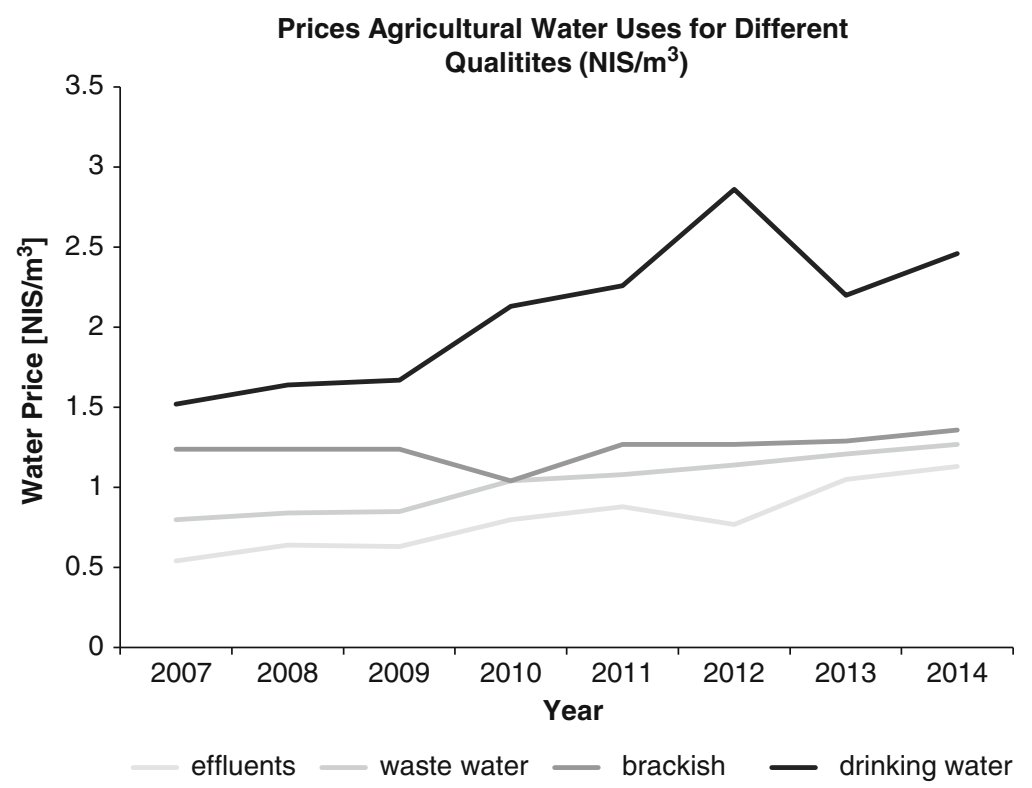

Fig. 16.7 Prices for agricultural water uses according to different qualities $\left(\mathrm{NIS} / \mathrm{m}^{3}\right)$. Prices were approximated (Data source: (Israel Water Authority 2014b, c), Israel Central Bureau of Statistics (2012))

water-pricing schemes have been implemented, there is a strong push, not only for reinvestments but also for extensions and "modernisations" of such infrastructures.

The price structure for water for agriculture differs according to the quality of the water used (Fig. 16.7). It is separated into drinking water quality, water coming from wastewater treatment plants, effluents and brackish water. The price for drinking water is set according to the costs of production, but does not include the sewage treatment component, subsidies and costs for the purchase of desalinated water. Therefore there is a cross-subsidy from the domestic to the agricultural water sector. Compared with the price increases for the industrial and the domestic sector, the price increases for the agricultural sector were quite moderate. Within the agricultural sector, the share of energy prices caused the highest increases for agricultural inputs; water price increases played a much less important role (Fig. 16.8).

Besides water pricing instruments, which are related to end users, water levies for extraction are fixed in order to charge the value of water at the source. Those levies apply mainly to those who do not purchase their water from Mekorot but extract it by themselves. The levies are directly paid to the State Treasury. Changes in levies are suggested by the Israel Water Authority and subject to approval by the Knesset Finance Committee (Kislev 2011). The levy is set as a purely fiscal burden as it does not consider the characteristics of the services supplied by the ecosystem (Kedmi 2005). However, the calculation for the levies differs between different purposes: water for agriculture and water for domestic and industrial uses. The allocation is determined for each producer licence (Israel Water Authority). The 


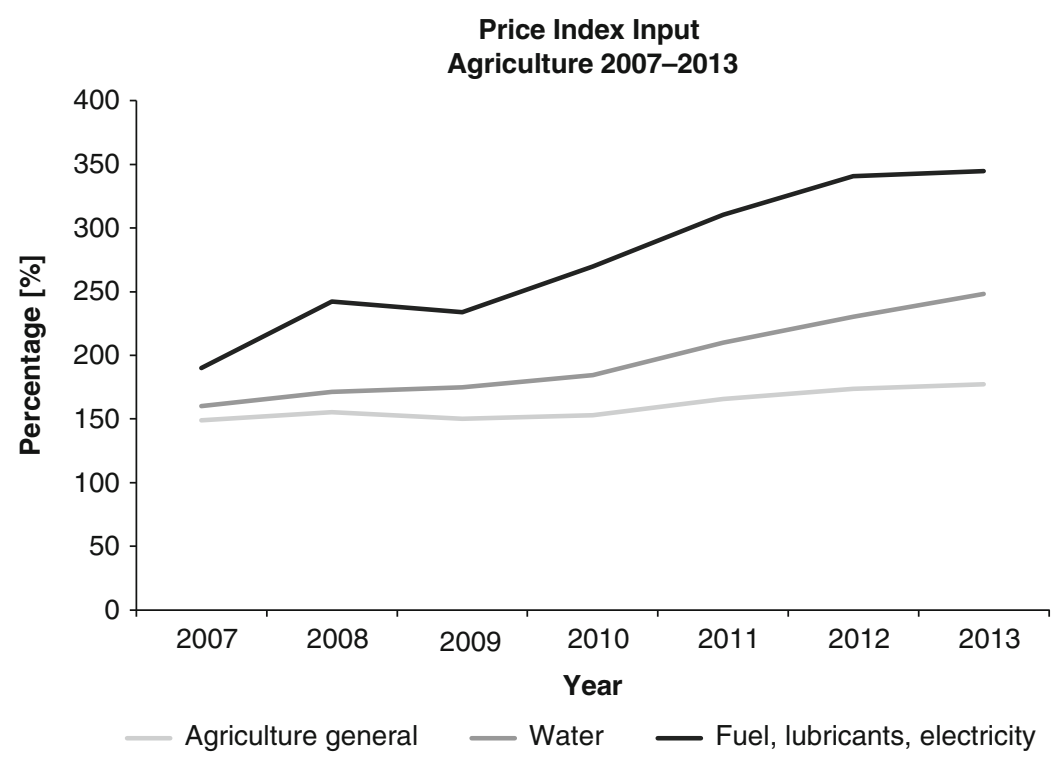

Fig. 16.8 Price index of input in agriculture from 2007 to 2013 (base year 2000=100) (Data source: Israel Central Bureau of Statistics 2013b)

levy level has increased steadily over the previous years, although not necessarily in accordance with the Israeli multi-annual plan (Kedmi 2005). The rates of the levies are determined on the basis of a number of parameters relating to the rate of water abstraction, the water production source, type and quality of water, hydrological situation, the purpose of the production and the quantity and type of the water produced (Israel Water Authority).

The levy system is divided into three regions: the country system area (in fact, those areas connected to the National Water Carrier), areas disconnected from the country system, and the Lake Tiberias area (ibid.).

Currently the levies for agricultural drilling within the country system are set at $50 \%$ of the regular rates. In addition, agriculture is exempted from VAT (ibid.). Here we notice again that the agricultural level is benefitting from different (implicit) subsidies.

There is also an ongoing discussion in Israel whether the potassium companies at the Dead Sea should continue to be exempted from the extraction levy. With $300 \times 10^{6} \mathrm{~m}^{3}$ water extraction per year, the companies significantly contribute to the decline of the Dead Sea (TAHAL and GSI 2011). The authors of the Study of Alternatives (Allan et al. 2014, p. 74) proposed a levy of USD $0.1 / \mathrm{m}^{3}$, under the condition that the income generated from the planed hydropower production (exploiting the elevation difference between the Red Sea and the Dead Sea) is included into the calculations.

But the technical feasibility of hydropower production based on saline water or brine was never investigated in the World Bank's study programme and was not part 
of the terms of reference for the different studies. There are sound reservations concerning realisation costs and lifetime of such a project: the generation of energy via salt water, or even brine will be achievable only with considerable technical effort in the use of corrosion-resistant materials. Maintenance and lifetime expectations will be not comparable to normal hydropower plants. It is estimated that the costs of the pipeline according to the plans of the water swap will be approx. USD 300 to USD 400 million (Udasin 2013). The construction of the pipeline will take 3-4 years and will cross the Jordanian part of the Arava Valley. The conveyance of the brine from the Red Sea to the Dead Sea would therefore raise the price of water by at least USD $0.25 / \mathrm{m}^{3}$ (on the basis of an amortisation period of the pipeline of 30 years). With respect to the polluter pays principle, a levy for the potash companies should at least be equivalent to the additional costs for water for conveying brine to the Dead Sea to compensate for uses upstream and from the Dead Sea Works themselves. For comparison, the costs of water for the restoration of the Lower Jordan River are about USD $0.10 / \mathrm{m}^{3}$ (Allan et al. 2012, p. 30).

\subsection{Awareness-Raising Measures}

In 2008 the Israel government and the Israel Water Authority started a comprehensive campaign to inform and raise awareness on reducing domestic water consumption. The installation of water-saving devices in private households and gardens and metering for the irrigation in private and public gardens were financially supported.

Another important measure to raise awareness is the online publication of water use data and of data on the groundwater levels in the different basins. The levels of Lake Tiberias are reported on a monthly basis and can be viewed on an online graph. Its level is an important communication instrument as droughts and water shortages can be visualised directly with the passing of the critical lake level red line. Also the level of the Dead Sea is published on a monthly basis, making extreme water stress in the region visible.

Furthermore, water prices are published on the Israel Water Authority website. All water data is publicly available and presented in a transparent manner.

\subsection{Discussion of Water Management Impacts}

Israel is a striking example of how long it may take (nearly 20 years) to effectively accomplish a shift in water management practices - even though the development in water stress in the region requires an even faster pace of change. Israel is likewise an example that land and water management are deeply rooted in the nation's values, which make it psychologically difficult to introduce changes, as one has to give up long-standing traditions and values. With regard to agriculture, Israel is far from 


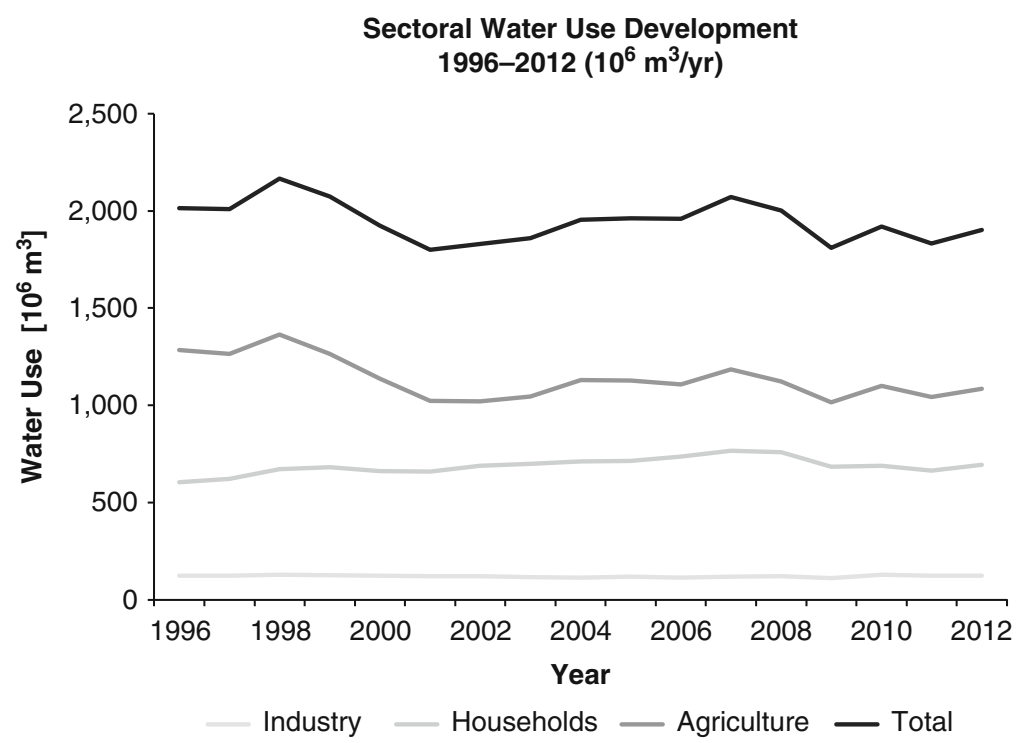

Fig. 16.9 Development of water uses for different sectors from 1996 to $2012\left(10^{6} \mathrm{~m}^{3}\right)$ (Data source: Israel Water Authority (2011), Israel Water Authority (2014))

giving up its "agricultural Zionistic ideal" despite the negligible economic importance of the agricultural sector which counts for only $1.4 \%$ of Israel's GDP.

Figure 16.9 reveals that changes in total water uses are mainly determined by decreases in agricultural water uses. Even though population increased considerably, domestic and industrial water uses remained nearly the same. However, this also means that per capita domestic water consumption decreased. The figure also indicates that the cuts in the water allocation for the agricultural sector in the late 1990 s had a greater impact on the reduction of the overall water consumption by the agricultural sector than the agricultural pricing policies after the water reforms starting in 2007.

This also applies for the use of drinking water in the agricultural sector, as a detailed analysis of the agricultural water consumption reveals (Fig. 16.10). Drinking water was mainly replaced by the use of treated sewage water. But still, with more than $400 \times 10^{6} \mathrm{~m}^{3}$ of drinking water consumed in 2012 , the agricultural sector uses a substantial amount of freshwater for irrigation purposes. This use goes along with prices, which only reflect the costs of the provision of water. However, the costs of seawater desalination and other investments costs, especially costs of the wastewater treatment infrastructures and the extension of the national water grid system, are still not included. If the cost recovery principle had been comprehensively applied to the agricultural sector, the sector would have been forced to pay water prices equivalent to those for private households. Thus the present pricing system only sets limited incentives for the agricultural sector in order to reduce its overall water uses. 


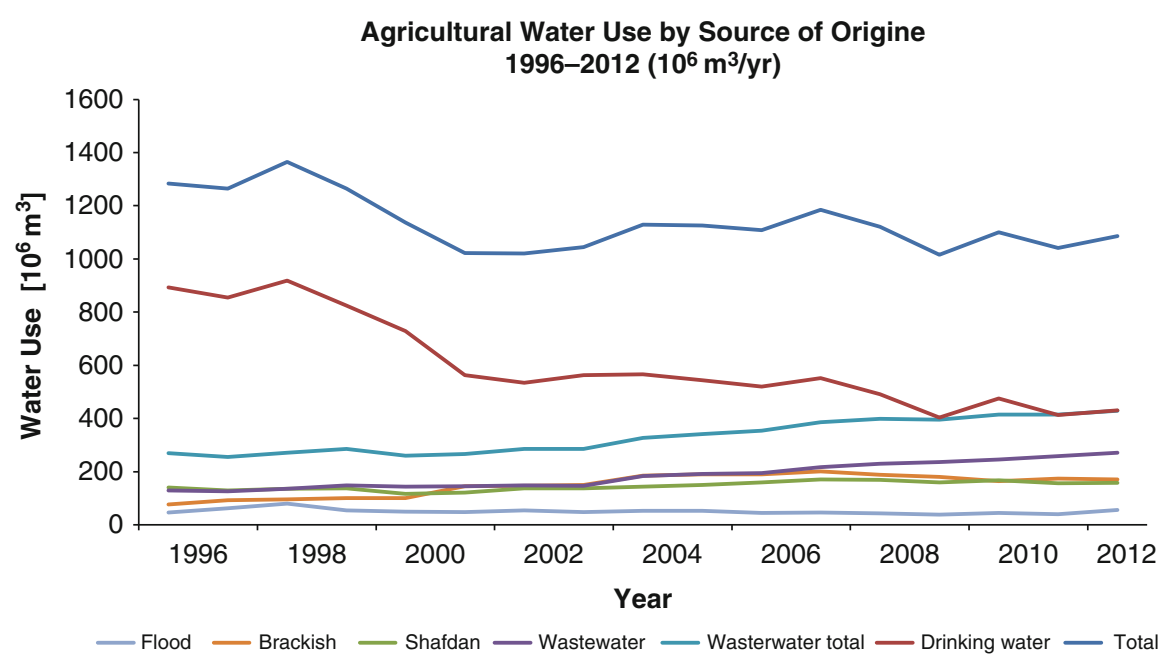

Fig. 16.10 Agricultural water uses divided into origin of source from 1996 to $2012\left(10^{6} \mathrm{~m}^{3}\right)$ (Data source: Israel Water Authority (2011), Israel Water Authority (2014a))

In some respect, Israel's water policy faces a dilemma: with the reduction of the household consumption of drinking water and the increased use of wastewater for public gardening (which also leads to a substitution of drinking water), there is less wastewater available, forcing the agricultural sector to use drinking water as a substitute to upholding its production. Practices in Israel's irrigation are of the highest state of knowledge, and their advanced techniques serve as a role model for the world. Although Israel is still undertaking major efforts in furthering increases in irrigation efficiency, its additional water-saving potential is limited due to the high standards already achieved. The only way to get out of this dilemma is either to reduce agriculture in some parts of the country or to convert the existing water-intensive agricultural practices to dry land agriculture. Becker et al. (2013) have produced evidence that it can be economically beneficial to give up agriculture for the rehabilitation of the Lower Jordan River.

Other regions in Israel with a high potential for recreation activities and rehabilitation of their ecosystems might also benefit from this. Israel is a country with a high population density, especially in the greater Tel Aviv area. Parks and pristine landscapes are a necessity for urbanised areas not only for their effects on the microclimate but also for the health and the well-being of the population. These ecosystem services might be of equal importance to the economic benefits obtained from agriculture.

Seawater desalination helped to sustain Lake Tiberias, but present allocations to the environment $\left(80 \times 10^{6} \mathrm{~m}^{3} /\right.$ year $)$ are not sufficient to successfully rehabilitate the Jordan River and the Dead Sea. If in the future all treated wastewater will be used for agriculture, conflicts will increase between agricultural use and the water needs of the landscape and the environment. The Kishon example shows that the rehabili- 
tation of rivers is far from being given priority within the Israel Water Authority. Israel's water management is highly centralised and linked to its scientific technocratic embedment. At present water planning mostly originates from this background, one of the reasons why water strategies have been criticised openly by the public and in politics. The civil society with its nature protection organisations and consumer protection groups is currently not represented in the water commission. A better representation of these groups might not make the decision-making process easier or shorter but in the end might lead to a better understanding and higher consensus within the Israeli society.

Pricing policies and levies to address the scarcity of natural resources as an incentive for water-saving measures are especially subject to differing interests and the volatile nature of political processes.

Many municipalities refuse to participate in the overall water allocations system. They expect a loss of independence and reduced potential for cross-subsidising other sectors (Kan and Kislev 2011). Improving civil society involvement and participation in water management planning processes could also help to reprioritise the objectives of water allocation and water pricing and increase support for unpopular measures within society.

Israel suffers not only from water shortages but also from increased income disparities and low welfare expenditures (Dahan and Hazan 2014). The outbreak of the social protests in summer 2011 is a reflection of these disparities. But water pricing would be the wrong instrument to mitigate these disparities. Low-income groups are supported by specific welfare programmes instead of lower water prices.

The restructuring process within Israel's water management has still not come to an end with regard to water corporations. Two specific problems are linked to this issue: the first is that there are far too many water companies in Israel, and the second is that under the uniform tariff structure system, companies who perform well have to support the ones who perform less well (Kan and Kislev 2011). This is due to water corporations with high water losses and high losses in water charges (because of compliance problems in water price payments) paying lower prices to Mekorot. To reemphasise - according to the equity principle, despite end-users' respective water resource use, all water prices are identical - subsequently this results in different costs in different regions. The government and Israel Water Authority need to find a way out of this dilemma (ibid.).

\subsection{Can Israel Serve as a Role Model? 10 Lessons to Be Learnt}

Israel has a very specific water management and the specificity of the availability of its water resources, technical facilities and governance structures limits the transferability of the Israeli experiences to other countries. Nevertheless, some lessons can 
be drawn from the Israeli case example. The first seven lessons are general in nature, while the last three refer to water pricing:

1. Innovative solutions to improve water supply and high technical standards are an important prerequisite to reduce water stress and improve the water situation. In Israel, major innovative technical solutions include new and innovative types of irrigation systems in the agricultural sector, highly innovative desalination systems, advanced wastewater treatment facilities for the reuse of water and the building of the corresponding infrastructure systems (e.g. water grid systems).

2. An important prerequisite for building up water-related infrastructures are sufficient financial resources. In Israel these resources have been made available since the foundation of the State of Israel. One important reason is that the agricultural sector received highest priority within the political discussions. Even though the significance of agriculture decreased in budgetary terms (in terms of the share of agriculture in the Israeli GDP), the agricultural sector is still seen as very important, and therefore, considerable public expenditure is devoted to this sector. A second reason for successfully financing the water sector lies in the raising of revenues from the users of water resources.

3. Nevertheless, it is not sufficient to just focus on water supply and the development and improvement of water infrastructure systems (and on the financing of these infrastructures). The improvement of existing and development of new water supply systems is a necessity, but not sufficient enough to improve the overall water situation. Technical supply measures have to be accompanied by management structures that complement technical developments, such as appropriate forms of governance and institutional reform. In Israel this has been achieved through comprehensive organisational reforms (the centralisation of powers) and the introduction of water prices intended to incentivise users to use water resources more effectively.

4. Strong institutions and the rule of law are preconditions for the successful implementation of water policy reforms, which are often neglected when policy makers and decision makers simply focus on technical solutions alone. If adequate institutional structures do not exist, policy reforms will fail. Even if technical solutions deliver success in the short run, links with institutional structures are decisive for long-term sustainability. Institution building and strengthening (with respect to water authorities, division of responsibilities between actors, regulation, etc.) are therefore necessary preconditions before any other reforms (such as pricing) can be introduced. Weak state institutions impact on other reforms in water policies.

5. Time is needed to successfully develop infrastructure systems, not only for technical reasons (long construction periods for large infrastructures) but mainly because they have to go hand in hand with institutional reform. As economic and societal rules are deeply embedded in society's legal system and culture, economic and societal changes have to be made gradually and with care. Even within highly centralised organised water management institutions as in Israel, the reshaping of the institutions (founding water authorities, defining and allocating 
competences, defining regulatory rules, etc.) and the introduction of new steering mechanisms (such as full cost recovery principle or water quotas for the agricultural sector) take many years or even decades. Therefore, there is the danger of seeing one of these elements (e.g. the cost recovery principle) as the "magic pill" that will solve all "ills" in water management alone.

6. Israel is an outstanding example of science, practice and government interacting closely together. Scientists play an important role in the water sector and in agricultural organisations. Especially in agriculture, this is one of the major reasons why technological pace has been so rapid. To increase efficiency, in particular for irrigation, this close system of interactions and relations between science and practice can truly serve as role models in other countries.

7. Israel is the only country in the region where water management and water policy are presented transparently. Anyone who would like information on water uses and water prices can obtain it. The credibility of water policies is enhanced by such an open and transparent information policy, even though there might be space for improvement, especially with respect to the participation of the civil society in the formulation of the water policy.

8. Water prices and levies play an important role in Israeli water policy. If properly designed, they can set incentives for water savings and an efficient use of water. A water price reform can therefore be an important supplement for water management strategies. However, in order to be successful in incentivising endusers' behaviour, water prices and levies should address the full cost of water (cost recovery principle) and the fair distribution of water prices among users.

9. With respect to cost recovery and allocative efficiency, it is important that all costs are included in the water price and that all sectors that use water are in fact obliged to contribute to the water pricing scheme. Cost recovery should not only be applied to a share of the user groups. However, in many countries, this will cause problems: the agricultural sector is seen as fundamental for the welfare of countries, leading to a deep-rooted need in societies to protect their agricultural sector and an automatic rejection of burdens such as water prices or levies.

10. Social equity may also be seen as a major obstacle to introducing the costrecovery principle on the level of domestic end users. Even in economically prosperous states such as Israel, water price policies are not disconnected from the overall social debate. The greater the income disparities, the more difficult will be the introduction of the cost recovery principle. Uniform tariff structures might be fair to the consumers but impede the efficiency of the local water utilities. This might only be a question for states with highly centralised water management institutions such as in Israel, but in many other regions under water stress, such centralised institutions are in place. Specific solutions have to be found to increase efficiency of the water utilities under such conditions.

Open Access This chapter is distributed under the terms of the Creative Commons Attribution Noncommercial License, which permits any noncommercial use, distribution, and reproduction in any medium, provided the original author(s) and source are credited. 


\section{References}

Aaronsohn R (1995) The beginnings of modern Jewish agriculture in Palestine: "Indigenous" versus “Imported.". Agric Hist 69:438-453

Allan JA, Malkawi AIH, Tsur Y (2014) Red Sea - Dead Sea water conveyance study program. Study of alternatives. Final report. Executive summary and main report. World Bank Publications, Washington, DC

Allan JA, Malkawi AIH, Tsur Y (2012) Red Sea - Dead Sea water conveyance study program. Study of alternatives. Preliminary draft report. World Bank Publications, Washington, DC

Amnesty International (2009) Troubled waters Palestinians denied fair access. Israel - occupied Palestinian Territories. Amnesty International Publications, London

Becker N (2010) Desalination and alternative water-shortage mitigation options in Israel: a comparative cost analysis. J Water Resour Prot 02:1042-1056. doi:10.4236/jwarp.2010.212124

Becker N, Helgeson J, Katz D (2013) Once there was a river: a benefit-cost analysis of rehabilitation of the Jordan River. Reg Environ Chang 14:1303-1314. doi:10.1007/s10113-013-0578-4

Cohen Y (2011) Seawater desalination and the environment - the Israeli experience. Paper presented at the 12th Israel desalination society annual conference, Haifa, 14-15 December 2011

Dahan M, Hazan M (2014) Priorities in the government budget. Israel Econ Rev 11:1-33

Dreizin Y, Tenne A, Hoffman D (2008) Integrating large scale seawater desalination plants within Israel's water supply system. Desalination 220(1):132-149

European Environment Agency (2014) Horizon 2020 Mediterranean report. Annex 3: Israel. Publications Office of the European Union, Luxembourg

Feitelson E (2013) The four eras of Israeli water policies. In: Becker N (ed) Water policy in Israel. Context, issues and options, 4th edn. Springer, Dordrecht/Heidelberg/London/New York, pp 15-32

Feitelson E, Fischhendler I, Kay P (2007) Role of a central administrator in managing water resources: the case of the Israeli Water Commissioner. Water Resour Res 43:1-11. doi:10.102 9/2007WR005922

Hansjürgens B (1997) Gebührenkalkulation auf Basis volkswirtschaftlicher Kosten? AnwendungsproblemeundLösungsmöglichkeite.In:Difu(ed)ArchivfürKommunalwissenschaften, vol 36. Kohlhammer, Stuttgart, pp 233-253

Hophmayer-Tokich S (2010) The evolution of national wastewater management regimes - the case of Israel. Water 2:439-460. doi:10.3390/w2030439

Israel Central Bureau of Statistics (2014) Gross domestic capital formation in infrastructure, by industry. Table 8A. In: National accounts 2006-2012. http://www1.cbs.gov.il/publications14/1553/pdf/t08a.pdf. Accessed 17 Feb 2015

Israel Central Bureau of Statistics (2013a) Sustainable development indicators in Israel 2011. Israel Central Bureau of Statistics (CBS), Jerusalem

Israel Central Bureau of Statistics (2013b) Input, output and domestic product in agriculture, Table 19.14. In: CBS, Statistical abstract of Israel 2013. http://www.cbs.gov.il/reader/shnaton/ templ_shnaton_e.html?num_tab=st19_14\&CYear=2013. Accessed 11 Feb 2015

Israel Central Bureau of Statistics (2012) Satellite account of water in Israel 2007-2008. Israel Central Bureau of Statistics (CBS), Jerusalem

Israel Ministry for Environmental Protection (2014) Kishon rehabilitation project frozen due to inaction by water authority. http://www.sviva.gov.il/English/ResourcesandServices/ NewsAndEvents/NewsAndMessageDover/Pages/2014/6June/Kishon-Rehabilitation-ProjectFrozen.aspx. Accessed 10 Oct 2014

Israel Water Authority (2012a) Israel water authority - towards WWF VI. http://www.water.gov.il/ Hebrew/ProfessionalInfoAndData/2012/01-Towards-WWF-VI.pdf. Accessed 10 Sep 2014

Israel Water Authority (2012b) Long-term master plan for the national water sector part A - policy document version 4. http://www.water.gov.il/Hebrew/Planning-and-Development/Planning/ MasterPlan/DocLib4/MasterPlan-en-v.4.pdf. Accessed 17 Feb 2015 
Israel Water Authority (2014a) Water Authority Report 2013. Israel Water Authority, Jerusalem (in Hebrew). http://www.water.gov.il/Hebrew/about-reshut-hamaim/DocLib/water-authorityreport-2013.pdf

Israel Water Authority (2014b) Prices archives (in Hebrew). http://www.water.gov.il/Hebrew/ Rates/Pages/prices-archive.aspx. Accessed 11 Dec 2014

Israel Water Authority (2014c) Production levies (in Hebrew). http://www.water.gov.il/hebrew/ rates/pages/producer-levies.aspx?p=print. Accessed 11 Dec 2014b

Israel Water Authority (2014d) Allocation, consumption and production data (in Hebrew). http:// www.water.gov.il/Hebrew/ProfessionalInfoAndData/Allocation-Consumption-andproduction/Pages/Local-authorities-data.aspx. Accessed 11 Dec 2014

Israel Water Authority (2011) Water consumption by sectors: 1996-2011 (in Hebrew). http://www. water.gov.il/Hebrew/ProfessionalInfoAndData/Allocation-Consumption-andproduction/.

Kan I, Kislev Y (2011) Urban water price setting under central administration. European Commission, Brussels

Kark R (1983) Millenarism and agricultural settlement in the Holy Land in the nineteenth century. J Hist Geogr 9:47-62. doi:10.1016/0305-7488(83)90141-X

Katz S, Ben-David J (1975) Scientific research and agricultural innovation in Israel. Minerva 13:152-182. doi:10.1007/BF01097793

Kedmi N (2005) Integrated water resources management in Israel. http://www.unece.org/fileadmin/DAM/env/water/meetings/payment_ecosystems/Discpapers/Israel.pdf. Accessed 11 Dec 2014

Kislev Y (2011) The water economy of Israel. Taub Center for Social Policy Studies in Israel, Jerusalem

Kislev Y (2013) Water in agriculture. In: Becker N (ed) Water policy in Israel. Context, issues and options. Springer, Dordrecht/Heidelberg/London/New York, pp 51-64

Lipchin C (2007) Water, agriculture and zionism: exploring the interface between policy and ideology. In: Lipchin C (ed) Integrated water resources management and security in the Middle East. Springer, Dordrecht, pp 251-267

Lokiec F (2011) Sorek 150 million $\mathrm{m}^{3} /$ year seawater desalination facility build. Operate and Transfer (BOT) Project. Paper presented at the IDA World Congress, Perth Convention and Exhibition Centre (PCEC), Perth, 4-9 September 2011

Menahem G, Gilad S (2013) Israel's water policy 1980s-2000: advocacy, coalitions, policy stalemate, and policy change. In: Becker N (ed) Water policy in Israel. Context, issues and options. Springer, Dordrecht/Heidelberg/London/New York, pp 33-50

OECD (2011) OECD environmental performance reviews: Israel 2011. OECD Publishing, Paris

Plaut S (2000) Water policy in Israel. Policy Stud 47:1-26

Spiritos E, Lipchin C (2013) Desalination in Israel. In: Becker N (ed) Water policy in Israel. Context, issues and options. Springer, Dordrecht/Heidelberg/London/New York, pp 101-124

TAHAL, GSI (2011) Dead Sea study (final report). http://siteresources.worldbank.org/ INTREDSEADEADSEA/Resources/Dead_Sea_Study_Final_August_2011.pdf. Accessed 14 Jan 2015

Tenne A (2010) Seawater desalination in Israel: planning, coping with difficulties, and economic aspects of long-term risks. Israel Water Authority, Tel Aviv

Tenne A, Hoffman D, Levi E (2013) Quantifying the actual benefits of large scale seawater desalination in Israel. Desalin Water Treat 51:26-37

Udasin S (2013) Israel, Jordan, PA sign trilateral agreements to "swap" and share water. In: The Jerusalem Post. http://www.jpost.com/Enviro-Tech/Exclusive-Israel-Jordan-PA-to-signtrilateral-water-swap-sales-agreements-334505. Accessed 16 Mar 2015

Water.org.il (2014) Water prices (in Hebrew). www.water.org.il. Accessed 1 Oct 2014 